\title{
Rhabdomyolysis induced by Isotretinoin
}

\author{
Gargantilla Madera $\mathrm{P}^{1,2^{*}}$, Martín Cabrejas $\mathrm{BM}^{3}$ and Pintor Holguín $\mathrm{E}^{2}$ \\ ${ }^{1}$ Department of Internal Medicine, Hospital de El Escorial, Madrid, Spain \\ ${ }^{2}$ University European of Madrid, Spain \\ ${ }^{3}$ Departmen of Gynecology and Obstetrics, Hospital University Foundation of Alcorcon, Madrid, Spain
}

Rhabdomyolysis is caused by necrosis of striated muscle cells and it has been defined as an elevation of creatine phosphokinase (CK) greater than 5 times the upper limit of normal. The rhabdomyolysis can be caused by trauma, overexertion, toxins (alcohol, drugs) or muscle metabolic defects. Drugs are common causes of rhabdomyolysis, usually statins and antipsychotics. We present a case of rhabdomyolysis during isotretinoin therapy [1].

A 18-year-old male started therapy with $40 \mathrm{mg}$ per day of isotretinoin $(0.5 \mathrm{mg} / \mathrm{kg} / \mathrm{day})$ for acne. In a routine examination conducted after 6 months the patient reported moderate fatigue. Blood tests revealed elevated CK with values of $39.800 \mathrm{IU} / \mathrm{l}$ (normal range, 24-204 UI/l). We recommended discontinue the isotretinoin therapy, avoidance of strenuous exercise and abundant fluid intake. After four weeks CK had returned to normal (56 UI/l).

Oral isotretinoin (13-cis retinoic acid) is a vitamin A derivated that it is effective for the treatment of severe recalcitrant nodular acne. This drug counteracts the pathogenic factors that contribute to the development of acne vulgaris. Treatment is initiated at a dose of $0.5 \mathrm{mg} / \mathrm{kg} /$ day and it is subsequently increased to $1 \mathrm{mg} /$ $\mathrm{kg} /$ day. Isotretinoin is associated with a number of adverse effects: causes spontaneous abortions and severe life-threatening congenital malformations, inflammatory bowel disease, dry skin and mucous membranes, epistaxis, cheilitis, desquamation, photosensitivity, pruritus, hypertriglyceridemia and myalgias [2]. Rhabdomyolysis may occur in patients taking oral isotretinoin, particularly those who engage in vigorous physical activity as our patient [3]. CK levels are elevated in approximately 15-50 percent of patients with isotretinoin-induced myalgias [4]. The elevation of CK is usually mild. In some patients is asymptomatic (with elevated CK in laboratory tests), in others they had severe muscle pain and weakness.

The management of isolated $\mathrm{CK}$ elevation is temporarily discontinuing isotretinoin (until CK levels return to normal) of decrease the dose. In these patients it is recommended to avoid strenuous exercise, it is believed that both can have a synergistic effect [4].

\section{References}

1. Guttman-Yassky E, Hayek T, Muchnik L, Bergman R (2003) Acuterhabdomyolysis and myoglobinuria associated with isotretinoin treatment. Int J Dermatol 42: 499-500. [Crossref]

2. Trauner MA, Ruben BS (1999) Isotretinoin induced rhabdomyolysis? A case report. Dermatol Online J 5: 2.[Crossref]

3. ColladoNavas R, CasadoGarcía R, Lozoya Serrano B (2006)Miopatíaporisotretinoína Semergen $32: 253$.

4. Brelsford M, Beute TC (2008) Preventing and managing the side effects of isotretinoin SeminCutan Med Surg 27: 197-206.[Crossref]
Copyright: (C)2016 Gargantilla Madera P. This is an open-access article distributed under the terms of the Creative Commons Attribution License, which permits unrestricted use, distribution, and reproduction in any medium, provided the original author and source are credited.
Correspondence to: Pedro Gargantilla, Department of Internal Medicine, Hospital de El Escorial, Madrid Ctra. Guadarrama-Escorial Km 6,255, 28200 El Escorial, Madrid, Spain, E-mail: pgargantilla@yahoo.es

Key words: rhabdomyolysis, isotretinoin, creatine phosphokinase

Received: January 20, 2016; Accepted: February 18, 2016; Published: February 22, 2016 